accepting the Prinkipo proposal to be couched in terms that were "studiously insulting" (Wilson's words). After Versailles the book tails off, as did American contacts with the Soviet government.

Gvishiani makes use of the rich Western literature on the subject, especially John Thompson's Russia, Bolshevism, and the Versailles Peace (from whom she cribs quotations without attribution), to present a reasonably well-rounded account of the formulation and direction of American policies toward the new Soviet state. On the Russian side, however, the portrayal is much more one-dimensional. Here her source is mainly the Dokumenty vneshnei politiki SSSR series, along with some passing references to the archives of the Soviet Ministry of Foreign Affairs. But the bland materials she quotes from that source add nothing of substance to what is already known.

The author's approach is to trace the diplomatic activities of the Soviet government vis-à-vis the United States straightforwardly and almost exclusively through the published notes sent out from Moscow. There are no insights provided on how Soviet policies were formulated, or any indication that some of them might have occasioned debates, or at least differences of opinion, within the high councils of the party, even when these matters are clearly indicated in the published Russian sources she uses. The main agent of policy is usually the "Soviet government," with Chicherin sending the notes and Lenin providing quotable remarks. Litvinov figures in events on a couple of occasions, but of course such nonpersons as Trotsky, Bukharin, Kamenev, and Zinoviev do not.

In short, then, about the only value of this monograph for Western specialists is that it once again demonstrates the problems Soviet historians face in dealing with sensitive historical subjects. Since most Westerners who might read the book are already well aware of these problems, there is little reason for them to bother.

PaUl Roley

Western Washington State College

\title{
CANADIAN-SOVIET RELATIONS BETWEEN THE WORLD WARS. By Aloysius Balawyder. Toronto and Buffalo: University of Toronto Press, 1972. ix, 248 pp. $\$ 12.50$.
}

The purpose of this book is to provide scholars and general readers with a longoverdue reference work on Canadian-Soviet relations during the interwar years. Part of the reason that such an account is overdue is the Canadian practice of withholding archival materials until long after the events. Those materials have only recently been made available. Another purpose is to show how CanadianSoviet relations were influenced by such factors as the economic and foreign policies of Great Britain, the revolutionary activities of the Comintern, the economic pressures within Canada and the Soviet Union, and the various group pressures in Canada. The latter include mainly the activities of ethnic groups, trade organizations and traders, the Communist Party of Canada, other Canadian parties, and surveys of editorial opinion throughout the country. Other themes not stressed in the preface are the effects of Canadian-Soviet relations on left-wing politics in Canada and the influence of the United States on Canadian policy.

The trade policy between the two countries treated chronologically provides the main thread of the book, most of the other themes being treated as they relate 
to trade. The major exception is chapter 10, "The Comintern and the Communist Party of Canada," in many ways the most interesting chapter in the book. Professor Balawyder is at his best in this chapter and those sections in which he deals with domestic left-wing politics and Soviet influence, real or trumped up, such as the IWW episode and the Winnipeg General Strike, both covered in chapter 2.

The book suffers from its brevity and the author's failure to extract any patterns from his various themes. Readers will find it a useful reference work, but they will have to draw the implications of most of the material for themselves. The theme best developed is the emergence of Canada from Britain's direction of policy-making to define its own national interest and the best means to serve it. The trade patterns, interest group activities, domestic conditions in both countries, and the influence of the United States are all left underdeveloped. This reader was disturbed to read that Soviet foreign policy was formulated and executed by the combination of Narkomindel, the Foreign Office, and the Comintern (p. 82). Later the author states that the Comintern shifted tactics according to the changing policies of the Communist Party of the Soviet Union (p. 172). The author also has an unfortunate tendency to infer Canadian public opinion without satisfactory evidence, though the information obtained from editorial opinion surveys is very interesting. To sum up, the book is not balanced and some themes are not adequately developed, but it is a valuable reference work.

\section{GEORGe Roseme Carleton University}

\section{LET SOVETSKO-AFGANSKIKH OTNOSHENII, 1919-1969. By $L . B$. Teplinsky. Moscow: "Nauka," 1971. 237 pp. 84 kopeks, paper.}

Afghanistan, the first state to offer recognition to Soviet Russia and the only neighbor from whom the USSR did not demand or acquire territory, has understandably attracted the attention of Soviet publicists and scholars. Nevertheless, before this work was published no one had made a systematic attempt to survey the history of Moscow-Kabul relations during the last half-century. L. B. Teplinsky's book contains a detailed analysis of political relations between the two countries as well as an excellent summary of Soviet (and satellite) economic, technical, and financial aid to Afghanistan, supplemented with details of scientific and cultural cooperation. Based on extensive research in Russian published and archival material (much of it made available for the first time), the volume constitutes an original and welcome contribution to the understanding of this complex problem. Unfortunately, however, this is not a definitive work, owing partly to circumstances beyond the author's control. Thus he is obliged to demonstrate the "nobility" of Soviet foreign policy: the USSR is "by its nature hostile to any imperialist aspirations," as evidenced by the repudiation in November 1917 of "all unequal treaties" secured by the tsarist government (p. 221). This assertion is belied by the author's own admission that one of the outstanding problems between Moscow and Kabul-the border along the Amu Darya (Oxus) River imposed on Afghanistan in 1873 - had not been resolved until 1946 (pp. 121-23). Significantly, Teplinsky does not choose to discuss the real reasons for Stalin's generosity. In a similar vein, in stressing the alleged harmoniousness of Soviet-Afghan relations, he underplays Kabul's anxiety over Moscow's post-1917 reoccupation of Central 